\title{
THE EFFECTS OF HEAT AND SODIUM ETHYL MERCURI-THIO-SALICYLATE ON THE STAPHYLOCOAGULASE TEST
}

\author{
BY \\ W. D. LINSELL AND R. H. GORRILL \\ From the Wright-Fleming Institute of Microbiology and the Department of Bacteriology, \\ St. Mary's Hospital Medical School, London
}

(RECEIVED FOR PUBLICATION JULY 7, 1950)

The ability of certain strains of staphylococci to clot plasma has been known since 1903 when it was first described by Loeb working with goose plasma. The value of this observation and its application to routine bacteriology did not become apparent until Chapman, Berens, Peters, and Curcio (1934) and Chapman, Berens, Nilson, and Curcio (1938) showed that coagulase was related to pathogenicity. Cruickshank (1937), investigating staphylocoagulase, showed that pathogenicity to rabbits and the production of coagulase were closely related.

Cadness-Graves, Williams, Harper, and Miles in 1943 described a slide test for the detection of coagulase-producing staphylococci, and showed that this method was closely correlated with the tube method used hitherto. Indeed, these two tests parallel one another so closely that they are commonly assumed to be manifestations of the same reaction.

While engaged in routine testing of staphylococci for their coagulase production, we found that, while the slide results were in accordance with the clinical diagnosis, the results of the tube test were consistently negative. At this time we were using a batch of American Army freeze-dried product as the source of our plasma. This discrepancy led us to the following investigations.

\section{Methods}

Tube Method.-An 18-hour broth culture of the staphylococcus, $0.1 \mathrm{ml}$., was added to $0.5 \mathrm{ml}$. of citrated human plasma diluted $1: 10$ with sterile normal saline in 4 in. $\times \frac{3}{8}$ in. tubes. This mixture was then incubated for two hours at $37^{\circ} \mathrm{C}$. in a water bath. A control consisting of the same plasma plus $0.1 \mathrm{ml}$. of sterile broth was set up in each group of tests.

Slide Method.-An 18-hour culture of the staphylococcus grown on plates of plain nutrient agar was used in the slide test. Two loopfuls of distilled water were placed on a clean slide and a sufficient amount of a single colony was emulsified to produce a homogeneous turbidity. A loopful of undiluted plasma was placed beside the staphylococcal suspension and the two mixed by rocking. With this technique nearly all positive strains give immediate clumping. Some doubtful and weak reactions required stirring with a loop to confirm the result. 
Reconstituted p'asma was made up in a concentration of $5 \mathrm{~g}$. of the dried product in $100 \mathrm{ml}$. of sterile distilled water to give a plasma of normal concentration. The staphylococci used were freshly isolated.

\section{Results}

The following results were obtained with reconstituted American freeze-dried plasma and with fresh citrated human plasma when tested against 63 strains of staphylococci (Table I).

TABLE I

Comparison of Fresh and Reconstituted Plasma in Coagulase. Testing of 63 Strains OF STAPHYLOCOCCI

\begin{tabular}{c|c|c|c|c|c}
\hline \multirow{2}{*}{$\begin{array}{c}\text { Total No. Staph. } \\
\text { Strains Tested }\end{array}$} & $\begin{array}{c}\text { Staphylococcal } \\
\text { Strains Tested }\end{array}$ & \multicolumn{2}{|c|}{ Tube Method } & \multicolumn{2}{c}{ Slide Method } \\
\cline { 2 - 6 } & $\begin{array}{c}\text { Fresh } \\
\text { Plasma }\end{array}$ & $\begin{array}{c}\text { Reconstituted } \\
\text { Plasma }\end{array}$ & $\begin{array}{c}\text { Fresh } \\
\text { Plasma }\end{array}$ & $\begin{array}{c}\text { Reconstituted } \\
\text { Plasma }\end{array}$ \\
\hline 63 & $\begin{array}{c}\text { No. positive } \\
\text { No. negative }\end{array}$ & $\begin{array}{c}48 \\
15\end{array}$ & $\begin{array}{c}0 \\
48\end{array}$ & $\begin{array}{c}48 \\
15\end{array}$ \\
\hline
\end{tabular}

As the slide test depends for its effect on the formation of a fibrin web which contracts and so clumps the staphylococci together, these results show that the reconstituted plasma still contains some of its original fibrinogen.

Thirty-seven strains of staphylococci were tested using dried plasma from the National Blood Transfusion Service. Complete correlation in both tube and slide tests was obtained when compared with fresh citrated human plasma.

The results of laboratory freeze drying were next observed;2-ml. samples of freeze-dried plasma were reconstituted at varying times after processing, and then tested with 10 strains of staphylococci. The first sample was reconstituted immediately after preparation, the rest at weekly intervals up to six weeks after freezedrying. From this it emerged that laboratory freeze-drying of plasma followed by storage at room temperature had no detectable effect on the reactions with staphylocoagulase within this time.

American freeze-dried plasma contains merthiolate (sodium ethyl mercuri-thiosalicylate) $1 / 50,000$ as a preservative, and the effect of this substance on the coagulase test was therefore investigated.

Fresh citrated human plasma was treated with merthiolate to give final concentrations of $1 / 10,000$ and $1 / 100,000$, the mixture being allowed to stand for 24 hours at $4^{\circ} \mathrm{C}$. At a concentration of 1 in 100,000 , merthiolate was found to have a retarding effect on the tube coagulase test which varied with the different strains of staphylococci as shown in Table II, whereas the slide test with plasma containing $1 / 100,000$ merthiolate showed complete correlation with the slide test using normal fresh plasma.

The effect of merthiolate at $1 / 10,000$ was next investigated. In this experiment none of the 16 positive strains of staphylococci clotted the plasma in the tube in two hours. Therefore a further reading was taken at 18 hours. Despite the 
TABLE II

Comparison of Normal Plasma and Normal Plasma Containing Merthiolate 1 in 100,000 (TUBE TEST)

\begin{tabular}{c|c|c}
\hline \multirow{2}{*}{ Total Number of Strains Tested } & \multicolumn{2}{|c}{16} \\
\cline { 2 - 3 } & Normal Plasma & Plasma+ Merthiolate \\
\hline Number of strains coagulase positive in 30 min.*.. & 15 & 0 \\
Number of strains coagulase positive in 60 min..$\cdots$ & 16 & 4 \\
Number of strains coagulase positive in 90 min. . & 16 & 10 \\
Number of strains coagulase positive in 120 min. .. & 16 & 14 \\
\hline
\end{tabular}

* Readings taken at 30-min. intervals up to 2 hours.

increased time the results were again negative. With normal fresh plasma all the positive strains gave a coagulum in 30 minutes.

In view of the fact that 24 hours' exposure to $1 / 10,000$ merthiolate at $4^{\circ} \mathrm{C}$. abolished the tube coagulase test, further experiments were undertaken with that sample of plasma to ascertain the effects of time of exposure to merthiolate on this phenomenon. The results in Table III show that the duration of contact between plasma and merthiolate has a direct relationship to the tube coagulation test.

TABLE III

Effect of Duration of Contact between Normal Plasma and Merthiolate $(1: 10,000)$

\begin{tabular}{|c|c|c|c|c|c|c|}
\hline & $\begin{array}{l}\text { Normal } \\
\text { Plasma }\end{array}$ & \multicolumn{5}{|c|}{$\begin{array}{c}\text { Duration of Contact between Plasma and } \\
\text { Merthiolate }\end{array}$} \\
\hline $\begin{array}{l}\text { Number coagulase positive } \\
\text { Number coagulase negative }\end{array}$ & $\begin{array}{r}16 \\
0\end{array}$ & $\begin{array}{l}1 \text { hour } \\
8^{*} \\
8\end{array}$ & $\begin{array}{c}2 \text { hours } \\
5 \dagger \\
11\end{array}$ & $\begin{array}{c}4 \text { hours } \\
2 \ddagger \\
14\end{array}$ & $\begin{array}{c}12 \text { hours } \\
0 \\
16\end{array}$ & $\begin{array}{c}24 \text { hours } \\
0 \\
16\end{array}$ \\
\hline
\end{tabular}

* Four of these strains were positive after $90 \mathrm{~min}$. and 4 after $120 \mathrm{~min}$. incubation ai $37^{\circ} \mathrm{C}$. + One strain positive after 90 min., 4 after 120 min. incubation. $¥$ Both positive after 120 min. incubation.

The possible mode of action of merthiolate was then studied. The ability of merthiolated plasma to clot in the presence of calcium ions and thrombokinase was confirmed.

The clotting time of normal citrated plasma was 18 seconds. This plasma was then treated with merthiolate to give a final concentration of $1 / 10,000$. The mixture was left for 24 hours at $4^{\circ} \mathrm{C}$. ; then its clotting time was estimated after the addition of calcium ions and thrombokinase, and found to be 21 seconds (average of three readings).

From Table I it will be seen that all the tube coagulase tests were negative whereas the slide results were normal using American reconstituted plasma. An investigation was carried out to determine if other methods would abolish the tube test while leaving the slide test unaffected. With this end in view the effect of heat on the tube and slide coagulase test was investigated.

Human plasma was taken from volunteers, immediately heated for varying periods at $56^{\circ} \mathrm{C}$., and then used in both slide and tube tests. Each batch of heated 
plasma was tested with strains of staphylococci. As the results in Table IV show, within four minutes of heating at $56^{\circ} \mathrm{C}$. the tube test was rendered completely negative while the slide test remained positive. It was noted, however, that the slide

TABLE IV

Effect of Heated Plasma on Tube and Slide Coagulase Testing of 20 Staphylococcal STRAINS

\begin{tabular}{|c|c|c|c|c|c|c|c|c|c|}
\hline & \multirow{2}{*}{ Coagulase } & \multirow{2}{*}{$\begin{array}{l}\text { Normal } \\
\text { Plasma }\end{array}$} & \multicolumn{7}{|c|}{ Heating Time (Min.) } \\
\hline & & & 1 & 2 & 4 & 8 & 15 & 30 & 60 \\
\hline Tube .. & $\begin{array}{l}\text { Positive } \\
\text { Negative }\end{array}$ & $\begin{array}{r}16 \\
4\end{array}$ & $\begin{array}{r}16 \\
4\end{array}$ & $\begin{array}{r}6 \\
14\end{array}$ & $\begin{array}{r}0 \\
20\end{array}$ & $\begin{array}{r}0 \\
20\end{array}$ & $\begin{array}{r}0 \\
20\end{array}$ & $\begin{array}{r}0 \\
20\end{array}$ & $\begin{array}{r}0 \\
20\end{array}$ \\
\hline Slide & $\begin{array}{l}\text { Positive } \\
\text { Negative }\end{array}$ & $\begin{array}{r}16 \\
4\end{array}$ & $\begin{array}{r}16 \\
4\end{array}$ & $\begin{array}{r}16 \\
4\end{array}$ & $\begin{array}{r}16 \\
4\end{array}$ & $\begin{array}{r}16 \\
4\end{array}$ & $\begin{array}{r}16 \\
4\end{array}$ & $\begin{array}{r}16 \\
4\end{array}$ & $\begin{array}{r}16 \\
4\end{array}$ \\
\hline
\end{tabular}

test, while positive in plasma heated for 30 and 60 minutes, showed a weaker coagulum than in the control.

The tests were repeated using the same dilution of plasma $(1: 10$ in the slide test as in the tube test) to investigate the possibility that the different concentrations of plasma in the usual tube and slide tests may have played some part in the results shown in Table IV. However, as is shown in Table V, the diluted plasma behaved in the same way as the undiluted.

TABLE V

Effect of Heating Diluted Plasma on Tube and Slide Coagulase Testing of 10 Staphylococcal Strains

\begin{tabular}{|c|c|c|c|c|c|c|c|c|c|}
\hline & \multirow{2}{*}{ Coagulase } & \multirow{2}{*}{$\begin{array}{c}\text { Normal } \\
\text { Plasma } \\
\text { Diluted } \\
1: 10\end{array}$} & \multicolumn{7}{|c|}{$\begin{array}{l}\text { Heating Time } \\
\text { (Min.) }\end{array}$} \\
\hline & & & 1 & 2 & 4 & 8 & 15 & 30 & 60 \\
\hline Tube . & $\begin{array}{l}\text { Positive } \\
\text { Negative }\end{array}$ & $\begin{array}{l}7 \\
3\end{array}$ & $\begin{array}{l}7 \\
3\end{array}$ & $\begin{array}{l}4 \\
6\end{array}$ & $\begin{array}{l}1 \\
9\end{array}$ & $\begin{array}{r}0 \\
10\end{array}$ & $\begin{array}{r}0 \\
10\end{array}$ & $\begin{array}{r}0 \\
10\end{array}$ & $\begin{array}{r}0 \\
10\end{array}$ \\
\hline Slide & $\begin{array}{l}\text { Positive } \\
\text { Negative }\end{array}$ & $\begin{array}{l}7 \\
3\end{array}$ & $\begin{array}{l}7 \\
3\end{array}$ & $\begin{array}{l}7 \\
3\end{array}$ & $\begin{array}{l}7 \\
3\end{array}$ & $\begin{array}{l}7 \\
3\end{array}$ & $\begin{array}{l}7 \\
3\end{array}$ & $\begin{array}{l}7 \\
3\end{array}$ & $\begin{array}{l}7 \\
3\end{array}$ \\
\hline
\end{tabular}

\section{Discussion}

The effect of heating and merthiolate in selectively destroying the tube coagulase activity of plasma while affecting the slide coagulase reaction much less or not at all has been demonstrated.

Wilson Smith and Hale (1944), investigating the mechanism of the tube coagulase test, showed that the plasma contributes a factor which enables staphylocoagulase to convert fibrinogen into fibrin. This factor is known as the activator substance and is heat labile. 
The mechanism of the slide coagulase test was investigated by Cadness-Graves et al., who showed that purified fibrinogen would work very well in the slide test in the place of plasma.

Both merthiolate and heating to $56^{\circ} \mathrm{C}$. modify human plasma in such a way that a tube coagulase test is invariably negative whereas the plasma still gives positive reactions when employed in the slide test. This effect suggests that there is some difference in the underlying mechanism of the two tests. The lability of the coagulase reacting factor in plasma suggests that it might be at this point in the coagulase mechanism that heat and merthiolate act.

\section{Summary}

Reconstituted plasma without a preservative is a satisfactory source of plasma for the tube and slide coagulase tests.

Reconstituted plasma with merthiolate as a preservative or fresh heated plasma does not provide a satisfactory plasma for the tube coagulase test, but gives good results in the slide test.

We wish to thank Dr. Cadness-Graves for advice and assistance with the references.

\section{REFERENCES}

Cadness-Graves, B., Williams, R., Harper, G. J., and Miles, A. A. (1943). Lancet, 1, 736.

Chapman, G. H., Berens, C., Peters, A., and Curcio, L. (1934). J. Bact., 28, 343.

- Nilson, E. L., and Curcio, L. G. (1938). Ibid., 35, 311.

Cruickshank, R. (1937). J. Path. Bart., 45, 295.

Loeb, L. (1903). J. med. Res., 10, 407.

Smith, W., and Hale, J. H. (1944). Brit. J. exp. Path., 25, 101. 